\title{
UNFAIR AND HARSH RESULTS OF CONTRIBUTORY NEGLIGENCE LIVES IN INDIANA: THE INDIANA MEDICAL MALPRACTICE SYSTEM AND THE INDIANA COMPARATIVE FAULT ACT
}

\author{
Bruce D. Jones*
}

\section{TABLE OF CONTENTS}

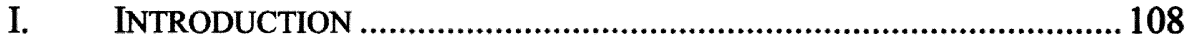

II. THE INDIANA MEDICAL MALPRACTICE ACT ................................... 109

A. The Legislative History of the Indiana Medical Malpractice Act

B. Major Provisions of the Medical Malpractice Act.

III. THE DOCTRINES OF CONTRIBUTORY NEGLIGENCE AND COMPARATIVE FAULT: TWO DEFENSES TO A MEDICAL MALPRACTICE CLAIM

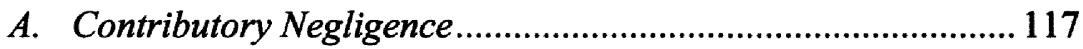

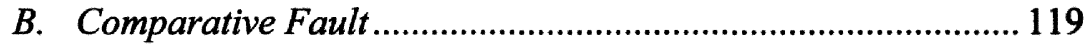

C. Comparative Fault in Indiana............................................... 122

1. Legislative History of the Comparative Fault Act ..............122

2. A Huge Comparative Fault Exception................................. 123

IV. THE STATE OF HEALTH CARE IN THE UNITED STATES: EXAMINATION OF MEDICAL MALPRACTICE LEGISLATION IN OTHER

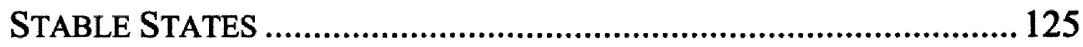

V. INDIANA SHOULD ABOLISH THE DOCTRINE OF CONTRIBUTORY NEGLIGENCE IN MEDICAL MALPRACTICE CASES........................... 130

A. The Effectiveness of the Indiana Medical Malpractice Act ...... 130

B. Contributory Negligence is Unfair, Harsh, and Ineffective ..... 131

C. Comparing Indiana to Other States Enjoying a Stable Health Care Environment.

D. The Effect of Adopting the Doctrine of Comparative Fault in the Modified Form on Health Care in Indiana

E. How Does the Law Get Changed? ..........................................134

VI. CONCLUSION

* J.D. Candidate 2009, Indiana University School of Law - Indianapolis; B.A. 2005 Washington University in St. Louis. I would like to thank my family (Tammy, Matt, and Claire) for all their understanding and sacrifice the last three years while I attended law school and completed this Note. I would also like to thank my Mom and Dad for always pushing me to achieve my goals and never allowing me to settle for second best. 


\section{INTRODUCTION}

In 1975, Indiana passed the Medical Malpractice Act in response to the growing health care crisis the state was facing. ${ }^{1}$ In doing so, Indiana became the first state to legislatively deal with the crisis by passing statutory reform measures. ${ }^{2}$ As a result, the Indiana statute became a model for other states to follow in order to deal with their own health care crises. ${ }^{3}$ Although Indiana was on the forefront of medical malpractice reform, it lagged behind in abolishing the doctrine of contributory negligence as a defense under its tort laws. It was not until 1983 that Indiana followed the majority of other states in abolishing the doctrine of contributory negligence and replaced it with the doctrine of comparative fault by passing the Comparative Fault Act. ${ }^{4}$ The Comparative Fault Act, however, specifically exempted medical malpractice claims, leaving the doctrine of contributory negligence in play as a defense against medical malpractice claims. ${ }^{5}$ By leaving contributory negligence defense available to health care professionals, the plaintiffs in a medical malpractice case could still face the harsh results inherent in the doctrine, ${ }^{6}$ including a complete bar to recovery. ${ }^{7}$ This result is inequitable and may be contradictory to the Indiana Constitution which guarantees every citizen a remedy for injuries caused by another individual. ${ }^{8}$ A more equitable approach to apply in medical malpractice cases is a modified comparative fault system. Under a modified comparative fault scheme, a patient would be allowed to recover if he was not more at fault than the physician for causing the resulting injury. ${ }^{9}$

This Note will first look at the Indiana Medical Malpractice Act, including the legislative history and findings that prompted the state legislature to pass the Medical Malpractice Act. Part I will also explore the major provisions of the Medical Malpractice Act which work to curb a resurgence of a health care crisis, including five provisions that are essential to protecting the health care environment and ensuring that adequate health care is available for all Hoosiers.

Part II and III of this Note will provide an overview of the doctrines of

1. H.R. 1460, 99th Gen. Assemb., Reg. Sess. (Ind. 1975).

2. Eleanor D. Kinney \& William P. Gronfein, Indiana's Malpractice System: No-Fault By Accident? 54 LAW \& CONTEMP. ProBs. 169, 169 (Winter 1991).

3. $I$ d.

4. 1975 Ind. Acts 1759.

5. IND. CoDE § 34-51-2-1 (2006).

6. See Cavens v. Zaberdac, 849 N.E.2d 526, 529 (Ind. 2006) ("Under Indiana law, the historic common law defense of contributory negligence remains available to defendants in cases alleging medical malpractice.").

7. Id. at n. 2. ("Thus the common law defense of contributory negligence, if proven, bars a patient from recovering any damages for injuries or losses that may have resulted from a physician's medical negligence.").

8. IND. CONST. ART. $1 \S 12$ ("All courts shall be open; and every person, for injury done to him in his person, property, or reputation, shall have remedy by due course of law.").

9. See infra note 114. 
contributory negligence and comparative fault. ${ }^{10}$ In examining the doctrine of contributory negligence, part II will examine how the doctrine works to serve a defendant in a negligence action, the criticisms of the doctrine, and why a majority of jurisdictions have abandoned it. In examining the doctrine of comparative fault, part III will discuss how comparative fault has replaced contributory negligence as a defense to negligence in most states, review the various forms of comparative fault which are used, as well as analyze how each applies to a negligence case. Finally, part III will look at the comparative fault system in the state of Indiana by discussing the legislative history of the Indiana Comparative Fault Act and the exceptions that are specifically provided under the statute. Further, part III will evaluate how these exceptions provide a great advantage to defendant-physicians and place another barrier to recovery in front of medical malpractice plaintiffs.

Part IV of this Note will analyze other states which have passed comprehensive medical malpractice legislation but use comparative fault in medical malpractice cases to demonstrate that the passage of comparative fault will not lead to another health care crisis in Indiana. Part IV will discuss the legislation in seven states that currently enjoy a stable health care environment. This part will detail the major provisions of each state's legislative acts that serve to prevent a potential health care crisis. Many of these provisions are similar or identical to those found in the Indiana statute. Part IV will also illustrate that the other seven states all apply the doctrine of comparative fault in cases based on a theory of medical malpractice.

In Part V, this Note will discuss how Indiana's contributory negligence system is unfair to plaintiffs injured by physician misconduct. The contributory negligence system is not serving to avoid another "health care crisis," but is instead placing another barrier in the plaintiff's path for receiving just compensation for his injuries. Part V will compare the Indiana method with that of the seven other states that enjoy a stable health care environment. It will also demonstrate that the provisions of the Medical Malpractice Act provide enough protections to prevent a recurrence of the health care crisis. In conclusion, this Note will discuss some ways in which Indiana's law could be changed.

\section{THE INDIANA MEDICAL MALPRACTICE ACT}

\section{A. The Legislative History of the Indiana Medical Malpractice Act}

In the mid-1970s, the Indiana General Assembly ("Assembly") conducted an extensive investigation into the causes of the health care crisis. As a result of the investigation, the Assembly passed the Medical Malpractice Act. ${ }^{11}$ Such

10. Many jurisdictions may term this doctrine "comparative negligence." This Note, however, will refer to it as "comparative fault" since that is the term used to label the Indiana statute.

11. H.R. 1460, 99th Gen. Assemb., Reg. Sess. (Ind. 1975). 
an act was needed due to a steep increase in the number of malpractice claims and lawsuits, ${ }^{12}$ an unreasonable increase in the size of judgments and settlements, ${ }^{13}$ and the effects of the increasing judgments and settlements on the entire health care system that were being felt by both patients and health care professionals throughout the state. ${ }^{14}$

The Assembly noted that the major effect of the health care crisis was due to the increasing cost of health care in the state-primarily the costs associated with physicians practicing defensive medicine to protect themselves from liabilities. ${ }^{15}$ The increased costs of defensive medicine were then being passed to the patients, ${ }^{16}$ resulting in patients having to pay more out of pocket costs and higher insurance premiums to receive needed medical care. ${ }^{17}$ The Assembly also took note of the drastic effects of obtaining liability insurance for the health care providers due to the increasing number of claims and judgments. ${ }^{18}$ The effects were felt by medical and hospital services in the state, ${ }^{19}$ but the most drastic effects were felt by the physicians themselves. Many liability insurance companies withdrew coverage or refused to cover physicians practicing in highrisk medical fields. ${ }^{20}$ As a result, many services were discontinued and became unavailable to Hoosiers. ${ }^{21}$ In fact, the Assembly noted that the rising cost of liability insurance was forcing health care providers to curtail all or part of their

12. H.R. $1460 \S 1$ (a), 99th Gen. Assemb., Reg. Sess. (Ind. 1975) ("The number of suits and claims for damages arising from professional patient care has increase[d] tremendously in the past several years...").

13. Id. (" $[T]$ he size of judgments and settlements in connection (suits arising from professional patient care) have increase unreasonable.").

14. Id. at $\S 1$ (b) ("The effect of [the increasing] judgments and settlements, base frequently on legal precedents, have caused the insurance coverage to uniformly and substantially increase the cost of such insurance coverage.").

15. Id. at $\S 1(\mathrm{e})$.

The rising number of suits and claims is forcing health care providers to practice defensively, viewing each patient as a potential adversary in a lawsuit, to the detriment of both the health care provider and the patient. Health care provide[r]s for their own protection, are often required to employ excessive diagnostic procedures for their patients, unnecessarily increasing the cost of patient care.

16. Id. at $\S 1(\mathrm{c})$.

17. Id.

18. H.R. $1460 \S 1$ (d), 99th Gen. Assemb., Reg. Sess. (Ind. 1975)

19. Id. at $\S 1(\mathrm{~h})$ ("The inability to obtain or the high cost of obtaining insurance affects the medical and hospital services available in the state of Indiana to the detriment of its citizens.").

20. Id. at $\S 1(\mathrm{~d})$.

The increased costs of providing health care services, the increased incidents of claims and suits against health care providers and the unusual size of such claims and judgments, frequently out of proportion to the actual damages sustained, has caused many liability insurance companies to withdraw from the insuring of high risk health care providers.

21. Id. at $\S 1(f)$ ("Another effect of the increase of suits and claims and the cost thereof is that some health care providers decline to provide certain health care services which in themselves entail some risk of patient injury."). 
practice. $^{22}$

The Assembly also noted a bigger problem with a longer lasting effect: the increased risk of practicing medicine was discouraging young individuals from pursuing a career in the medical profession, especially in high-risk fields. ${ }^{23}$ As a result, the cumulative effect of the Assembly's findings was deterring both citizens and professionals living and working in Indiana. ${ }^{24}$ Therefore, in order to deal with the effects of the health care crisis, the Assembly passed the Medical Malpractice Act ("MMA") for the purpose of curbing the effects and stopping the health care crisis facing Indiana. ${ }^{25}$

\section{B. Major Provisions of the Medical Malpractice Act}

Participation as a qualified or eligible provider under the MMA is voluntary. ${ }^{26}$ Therefore, the MMA does not bind physicians who choose not to participate. A physician who chooses not to become qualified, however, is not able to seek the MMA's protections in the event a suit arises. ${ }^{27}$ Thus, this provision indirectly blocks a potential health care crisis by defining qualified physicians who are eligible to seek the protections of the MMA, thereby lowering their malpractice insurance premiums while simultaneously providing a source of funding the state can use to payout claims brought against a qualified physician.

The MMA has five major provisions which propose to curb the effects of the health care crisis. The first major provision defines providers who are eligible under the $\mathrm{MMA}^{28}$ by setting out the requirements that must be met in order to qualify for protection under its provisions. ${ }^{29}$ To qualify, the provider

22. Id. at $\S 1$ (i) ("Some healthcare providers have been forced to curtail the practice of all or a part of their profession because of the non-availability or high cost of liability insurance.").

23. Id. at $\S 1$ (g) ("The cost and difficulty in obtaining insurance for health care providers discourages young physicians from entering into the practice of medicine in the state of Indiana, resulting in the loss of physicians to other states.").

24. H.R. $1460 \S 1$ (j), 99th Gen. Assemb., Reg. Sess. (Ind. 1975) ("The cumulative effect of suits and claims is working both to the detriment of the health care providers and to the citizens of this state.").

25. H.R. $1460 \S 2,99$ th Gen. Assemb., Reg. Sess. (Ind. 1975):

Because of the conditions stated in Section 1, it is the purpose of this act to establish a system by which a person who has sustained bodily injury or death as a result of tort or breach of contract on the part of a health care providers resulting from professional services rendered, or which should have been rendered, can obtain prompt determination and adjudication of his claim and fair and reasonable compensation at a fair and reasonable cost, from financially responsible health care providers who are able to insure their potential liability at reasonable affordable rates.

26. IND. CODE § 34-18-3 (2006).

27. IND. CODE $\S 34-18-3-1$ (2006) ("A health care provider who fails to qualify under this article is not covered by this article and is subject to liability under the law without regard to this article. If a health care provider does not qualify, the patient's remedy is not affected by this article.")

28. IND. CoDE § 34-18-3-2 (2006).

29. Id. The statute provides: 
must pay a surcharge $e^{30}$ that is charged annually by the state. ${ }^{31}$ The purpose of the income is to provide a source of money that will be used to fund a patient's compensation fund, ${ }^{32}$ which provides plaintiff-patients with compensation for the negligence of a physician. ${ }^{33}$

The second major provision, and likely the most important in dealing with the health care crisis, is the comprehensive cap that is placed on damages. ${ }^{34}$ The MMA limits both economic and punitive damages to 1.25 million dollars ${ }^{35}$ per occurrence. Placing a limit on recoverable damages is the best and most direct way to curb high insurance cost pressures on medical professionals. ${ }^{36} \mathrm{~A}$ cap provides a great benefit to providers by keeping insurance premiums for malpractice liability coverage to a minimum. ${ }^{37}$ By capping damages, insurance companies know the highest judgment or settlement they will be required to pay should a malpractice suit arise. With this provision, the MMA deals directly with the problem of the "long tail" 38 of liability that faces insurance carriers.

The "long tail" in a policy is usually found under "occurrence based" medical liability insurance policies. ${ }^{39}$ Under this type of policy, the "tail" of coverage insures the provider for all future claims that arise out of acts or omissions that occur during the period of actual coverage. ${ }^{40}$ The "long tail" creates a great deal of uncertainty about how much coverage would be needed and the exact period of time the policy needs to cover a physician. Under the MMA, the uncertainty of the amount of coverage needed to cover the "long tail" is no longer a factor. ${ }^{41}$ The damage cap sets the ceiling on the amount of liability for

For a health care provider to be qualified under this article, the health care provider or the health care provider's insurance carrier shall:

(1) cause to be filed with the commissioner proof of financial responsibility established under IC 34-18-4; and

(2) pay the surcharge assessed on all health care providers under IC 34-185 .

30. IND. CODE § 34-18-3-2(2) (2006).

31. IND. CODE $\S 34-18-3-5(2006)$.

32. IND. CODE § 34-18-3-2(2) (2006).

33. See infra pp. 16, 19-20.

34. IND. CODE § 34-18-14-3 (2006).

35. Id. Since the Act was first past in 1975, the Indiana General Assembly has modified this section numerous times to keep pace with the changing economical culture. Id.? Claims filed before January 1,1990 had a damage cap of $\$ 500,000$. Id. Claims filed on January 1 , 1990 to July 1,1999 were capped at $\$ 750,000$. Id. Claims filed after July 1, 1999 are capped at $\$ 1.25$ million. Id. There has been no adjustment since 1999 and $\$ 1.25$ million is the current damage cap for the state. $I d$. The fact that there has not been an adjustment has served as a point of contention and the General Assembly draws much criticism for not moving quicker to adjust the damage cap limit in the 21st Century. IND. CODE § 34-18-14-3(2006).

36. Steven E. Pegalis, 2 AM. LAW. MED. MaL. § 9:3 (July 2007).

37. Id.

38. In re Lavigne, 114 F.3d. 379, 382 (2d Cir. 1997) ("Tail coverage is insurance coverage that becomes effective upon the cancellation or termination of a policy.")

39. Lehigh Valley Health Network v. Executive Risk Indemn., Inc. 2001 WL 21505 (E. D. Pa. 2001).

40. Ballow v. PHICO Inc. Co. 841 P.2d 344, 348 (Colo. App., 1992), rev'd on other grounds 875 P.2d 1354 (Colo. 1993).

41. See generally Pegalis, supra note 36 , at $\S 9.3$. 
which the insurance carrier will be responsible. Thus, the insurance companies can tailor a plan, knowing the exact amount of liability for which it may be responsible, and thereby save the provider the expense of extra premium payments to adjust for the unknown. ${ }^{42}$ The damage limitations provision of the MMA also limits the financial amount that a defendant-physician, through his carrier, will be liable to pay in each case up to $\$ 250,000 .{ }^{43}$ This provision benefits both the insurance carriers and the providers by giving a firm amount of liability the doctor must pay out-of-pocket. ${ }^{44}$ Any remaining award is paid by the Patient's Compensation Fund. ${ }^{45}$ This is also a valuable feature of the MMA that serves to keep insurance premiums at an affordable rate. ${ }^{46}$ Finally, MMA limits damages by allowing only one recovery for each distinct act of medical malpractice that results in harm. ${ }^{47}$ If there are multiple instances of malpractice during one surgical procedure, the plaintiff may recover for each act of malpractice and each recovery is subjected to the statutory damages cap. ${ }^{48}$

The next major provision of the MMA is the creation of a Medical Review Panel ("Panel"). ${ }^{49}$ The purpose of the Panel is to review proposed medical malpractice claims filed against qualified physicians who are eligible under the MMA provisions. ${ }^{50}$ Either party can convene the panel twenty days after a complaint is filed. ${ }^{51}$ The Panel itself consists of four members: ${ }^{.2}$ an attorney who serves as the Panel chairperson and is a resource to the other members for interpretation of the law but has no voting power, ${ }^{53}$ and three members who must be physicians practicing in Indiana. ${ }^{54}$ All health care providers who practice in Indiana, with the exception of physicians functioning solely as health facility administrators, are eligible to serve as Panel members. ${ }^{55}$ The eligible pool of providers consists of all licensed providers regardless of the area of medicine they practice in. ${ }^{56}$ The only caveat is that two of the physician mem-

42. See $I d$.

43. IND. CODE § 34-18-14-4 (b) (2006) (“A health care provider qualified under this article (or IC 27-12 before its repeal) is not liable for an amount in excess of two hundred fifty thousand dollars $(\$ 250,000)$ for an occurrence of malpractice.").

44. See Pegalis, supra note 36 , at $\S 9.3$.

45. See infra pp. 14-16. This section will explain how the patient compensation fund is utilized when damages are awarded or a settlement is reached where are the amount recoverable is greater than $\$ 250,000$.

46. See generally Pegalis, supra note 35 , at $\S 9.3$.

47. See Patel v. Barker, 742 N.E.2d 28 (Ind. App. 2001).

48. Id.

49. IND. CODE § 34-18-10-1 (2006).

50. Id.

51. IND. CODE § 34-18-10-2 (2006) ("Not earlier than twenty (20) days after the filing of a proposed complaint, either party may request the formation of a medical review panel by serving a request by registered or certified mail upon all parties and the commissioner.").

52. IND. CODE § 34-18-10-3(a) (2006).

53. IND. CODE § 34-18-10-3(b) (2006). "The attorney member of the medical review panel shall act as chairman of the panel and in an advisory capacity but may not vote."

54. IND. CODE. § 34-18-10-3(a) (2006).

55. IND. CODE § 34-18-10-5 (2006).

56. Id. (Even licensed providers that practice the profession in an academic setting are 
bers must practice in the same field as the defendant. ${ }^{57}$ For example, if the physician practices in a highly specialized field such as cardiology, two of the el members must also practice cardiology. ${ }^{58}$ The requirement that two members of the Panel practice in the defendant's specialty only applies when there is ly one defendant. ${ }^{59}$ If there is more than one defendant, then the physicianmembers of the Panel can be selected without the specialization requirement. ${ }^{60}$

Once selected, the parties submit written evidence to the Panel as required by the MMA before any court proceeding can commence against a qualified provider. ${ }^{61}$ The Panel reviews the submissions and then renders an expert opinion. ${ }^{62}$ The MMA gives the Panel the authority to render four different opinions. ${ }^{63}$ The benefit of the Panel is that it allows both parties to gauge the

eligible to serve as panel members.).

57. IND. CODE § 34-18-10-8 (2006).

58. Id.

59. Id. The statute provides:

If there is only one (1) party defendant who is an individual, two (2) of the panelists selected must be members of the profession identified in IC 3418-2-14(1) of which the defendant is a member. If the individual defendant is a health care professional who specializes in a limited area, two (2) of the panelists selected must be health care professionals who specialize in the same area as the defendant.

60. James R. Fisher and Debra H. Miller, 23 IND. PRAC. §11:13 Personal Injury Law \& Practice (2008):

This requirement does not hold true in multiple defendant cases. In that event, there are no requirements as to what specialties must be represented on the panel. Often the parties agree as to what specialties should be on the panel. If a party fails to make its selection within the specified time period, the chairman makes the selection.

61. IND. CODE § 34-18-8-4 (2006):

Notwithstanding section 1 of this chapter, and except as provided in sections 5 and 6 of this chapter, an action against a health care provider may not be commenced in a court in Indiana before: (1) the claimant's proposed complaint has been presented to a medical review panel established under IC 34-18-10 (or IC 27-12-10 before its repeal); and (2) an opinion is given by the panel.

62. IND. CODE § 34-18-10-22(a) (2006). ("The panel has the sole duty to express the panel's expert opinion as to whether or not the evidence supports the conclusion that the defendant or defendants acted or failed to act within the appropriate standards of care as charged in the complaint.").

63. IND. CODE § 34-18-10-22(b) (2006):

After reviewing all evidence and after any examination of the panel by counsel representing either party, the panel shall, within thirty (30) days, give one (1) or more of the following expert opinions, which must be in writing and signed by the panelists: (1) The evidence supports the conclusion that the defendant or defendants failed to comply with the appropriate standard of care as charged in the complaint. (2) The evidence does not support the conclusion that the defendant or defendants failed to meet the applicable standard of care as charged in the complaint. (3) There is a material issue of fact, not requiring expert opinion, bearing on liability for consideration by the court or jury. (4) The conduct complained of was or was not a factor of the resultant damages. If so, whether the plaintiff suf- 
strength or weakness of their case before incurring the high cost of going to trial. The Panel's opinion may also encourage the parties to settle the case rather than endure a full trial. Finally, the Panel's expert opinion "is admissible as evidence in any action subsequently brought by the claimant in a court of law."64

The fourth major provision of the MMA is the creation of a state run $\mathrm{Pa}$ tient Compensation Fund ("PCF"). 65 The PCF is administered by the Indiana Department of Insurance ("IDOI") ${ }^{66}$ and overseen by the insurance commissioner who has a great deal of authority to protect the fund. ${ }^{67}$ The PFC is used to pay out large medical malpractice claims levied against an eligible provider. ${ }^{68}$ The monies used for the fund are collected from the proceeds of the eligible physician's annual surcharge. ${ }^{69}$ After the surcharges are collected from the providers who opt to participate in the MMA, the money is turned over to the PCF and the commissioner has wide latitude on how to secure additional funds. ${ }^{70}$ The PFC takes effect when a claim exceeds $\$ 250,000 .^{71}$ The health care professional's primary insurer is required to pay up to $\$ 250,000$ either by judgment of more than $\$ 250,000$ or by agreeing to settle for $\$ 250,000$ and then the court orders a remedy in excess of that amount. ${ }^{72}$ Another major provision of this section prevents a physician from refusing to settle. ${ }^{73}$ After a settlement or judgment is reached, the defendant hospital or physician is removed from the

fered: (A) any disability and the extent and duration of the disability; and

(B) any permanent impairment and the percentage of the impairment.

64. IND. CODE $\S 34-18-10-23$ (2006).

65. IND. CODE § 34-18-6-1 (2006).

66. Kinney, supra note 2.

67. IND. CODE § 34-18-6-2 (2006):

(a) The commissioner, using money from the fund, as considered necessary, appropriate, or desirable, may purchase or retain the services of persons, firms, and corporations to aid in protecting the fund against claims. The commissioner shall retain the services of counsel described in subsection (b) to represent the department when a trial court determination will be necessary to resolve a claim against the patient's compensation fund. (b) When retaining legal services under subsection (a), the commissioner shall retain competent and experienced legal counsel licensed to practice law in Indiana to assist in litigation or other matters pertaining to the fund.(c) The commissioner has sole authority for the following: (1) Making a decision regarding the settlement of a claim against the patient compensation fund. (2) Determining the reasonableness of any fee submitted to the department of insurance by an attorney who defends the patient compensation fund under this section. (d) All expenses of collecting, protecting, and administering the fund shall be paid from the fund.

68. IND. CODE § 34-18-6-6 (2006). See also Kinney, supra note 2, at 174.

69. IND. CODE § 34-18-6-1(c) (2006).

70. IND. CODE § 34-18-6-1(b) (2006). ("The fund and any income for the fund shall be held in trust, deposited in a segregated account, invested and reinvested by the commissioner as authorized by IC 27-1-13 and does not become part of the state general fund.")

71. Kinney, supra note 2 , at 174.

72. Id.

73. IND. CODE § 34-18-6-6(a) (2006). 
process and the PCF comes into play. Once the PCF becomes involved, the provider's liability is admitted. ${ }^{74}$ After liability is admitted and the physician's annual aggregate has been depleted, the physician may not object or refuse to settle the claim. ${ }^{75}$ Thus, this provision of the MMA positions the State as the insurer for a large portion of a medical malpractice claim if the judgment grants the maximum recovery to the claimant.

The final major provision of the MMA is the shortened statute of limitations period. ${ }^{76}$ In Indiana, a claim against a health care provider must be filed within two years of the MMA act resulting in the injury. ${ }^{77}$ The statute was intended to be an occurrence-based statute. ${ }^{78}$ The Indiana Supreme Court, however, has recently held that the law cannot preclude recovery from an individual whose disease or injury does not manifest itself within the statutorily required period of time. ${ }^{79}$ Thus, while the court recognizes the statute as occurrencebased, it has cut out a "discovery rule" niche for specific cases that could impose liability on health care professionals years after the alleged malpractice takes place. ${ }^{80}$

The MMA also features a tolling of the statute of limitations. The statute of limitations is tolled at the time a complaint is filed with IDOI. ${ }^{81}$ The tolling effect includes any periods of time that the case is being considered by the Panel to ninety days after the Panel has rendered its decision. ${ }^{82}$ Thus, this provision prevents a defendant-physician from requesting the convening of a Medical Review Board and using the MMA to insure the statute of limitations runs, and then claiming the statute of limitations defense in any subsequent judicial proceeding. A plaintiff must file their claim with IDOI to toll the statute of limitations. ${ }^{83}$ A medical malpractice claim is not considered "filed" until it is "mailed by certified mail to the Commissioner of the Department of

74. Kinney, supra note 2, at 175.

75. IND. CODE § 34-18-6-6(a) (2006).

76. IND. CODE $\S 34-18-7-1(2006)$.

77. IND. CoDE $\S 34-18-7-1$ (b) (2006).

A claim, whether in contract or tort, may not be brought against a health care provider based upon professional services or health care that was provided or that should have been provided unless the claim is filed within two

(2) years after the date of the alleged act, omission, or neglect, except that a minor less than six (6) years of age has until the minor's eighth birthday to file.

78. Havens v. Ritchy, 582 N.E.23 792 (Ind. 1991) (holding that the statue is an occurrence-based statute and "begins to run on the date of the alleged malpractice").

79. Martin v. Richey, 711 N.E.2d 1273 (Ind. 1999) ("The statue is unconstitutional as applied to plaintiffs who would be precluded from pursuing a claim because the disease or condition would not manifest significant pain or symptoms until several years after the asserted malpractice.")

80. Id.

81. IND. CODE § 34-18-7-3 (2006).

82. IND. CODE § 34-18-7-3 (2006).

83. Comer v. Gohil, 664 N.E.2d 389 (Ind. Ct. App. 1996). 
Insurance. ${ }^{84}$ If the plaintiff mistakenly files in court and not with IDOI, the statute of limitations is not tolled. ${ }^{85}$ Conversely, if the plaintiff files with IDOI and the health care provider is not qualified under the MMA, the plaintiff is notified and the running of the statute of limitations resumes. ${ }^{86}$

\section{THE DOCTRINES OF CONTRIBUTORY NEGLIGENCE AND COMPARATIVE FAULT: TWO DEFENSES TO A MEDICAL MALPRACTICE CLAIM}

\section{A. Contributory Negligence}

The defense of contributory negligence in a negligence action was first recognized in England in $1809^{87}$ and is defined as actions on the part of the injured party which fall below the standard ${ }^{88}$ of what a reasonable person would do to protect himself. ${ }^{89}$ In the legal context, the plaintiff's actions combine with the defendant's negligence to cause the actual harm. ${ }^{90}$ The doctrine of contributory negligence is founded under common law principles. Under the doctrine, an injured person whose own negligence results in harm to himself is not allowed to recover for the negligence of another ${ }^{91}$ if the injury would not have occurred had the injured party followed the standard of care he owed himself. $^{92}$ The effect of the doctrine is to bar any recovery for a person's failure to exercise "ordinary care" for his own well being which is found to be the "proximate cause" of the harm. ${ }^{93}$ Built into the rule is an "all or nothing" recovery system. ${ }^{94}$ No matter how slight the plaintiff's actions were in causing harm, a negligent plaintiff cannot recover any damages from a negligent defendant. ${ }^{95}$

If the defense of contributory negligence is asserted, the plaintiff's contri-

84. Id. (emphasis added).

85. Id.

86. Lusk v. Swanson, 753 N.E.2d 748, 751-752 (Ind. Ct. App. 2001) (holding that if a defendant-physician is not a qualified health care provider under the MMA, the statute of limitations is tolled from the point that IDOI received the complaint and begins to run again once the plaintiff is notified of the defendants disqualification.)

87. Steven Gardner, Contributory Negligence, Comparative Negligence and Stare Decisis in North Carolina. 18 CAMPBELL L. REV. 1, 5 (1996). For a comprehensive look at the early history of the Contributory Negligence Doctrine in England and the Untied States see id. at 5-9.

88. RESTATEMENT (SECOND) OF TORTS $§ 464$ (1963) (setting out the standard of conduct a person should follow for his own protection).

89. RESTATEMENT (SECOND) OF TORTS § 263 (1963). See also 57 B AM. JUR. 2D Negligence $§ 797$ (2004).

90. Id.

91. 57B AM. JUR. 2D Negligence $§ 798$ (2004) ("The law of contributory negligence is applicable only where both parties are at fault, and when the plaintiff could not by ordinary care have avoided the injury which the defendant's negligence produced.").

92. Id.

93. Id.

94. 57B AM. JUR. 2D Negligence § 799 (2004).

95. Id. 
bution to the injury is determined by conducting a two step analysis. ${ }^{96}$ First, the trier of fact determines if both the plaintiff and the defendant were negligent. ${ }^{97}$ If both parties are found to be negligent, the fact finder then compares the negligence of the plaintiff to that of the defendant. ${ }^{98}$ For a finding of fact on the issue of contributory negligence, the jury must find that the plaintiff satisfies each of the doctrine's three elements. ${ }^{99}$ If the fact finder finds any percentage of negligence on the part of the plaintiff, then the plaintiff is barred from recovery. ${ }^{100}$

The doctrine of contributory negligence has been criticized as an unjust doctrine because it may bar a plaintiff from recovery even if that plaintiff was only slightly negligent. ${ }^{101}$ Forty-six states have found contributory negligence to be inequitable and have abrogated the doctrine in favor of comparative fault. ${ }^{102}$ The West Virginia Supreme Court of Appeals held that the doctrine's harsh results were against public policy. ${ }^{103}$ Another major criticism of contributory negligence is the negative view the doctrine leaves on the courts that uphold the doctrine. ${ }^{104}$ Jurors understand the harsh results of the doctrine, which may lead jurors to turn to the practice of "substantial justice."105 Under this practice, the jurors find the defendant $100 \%$ liable to avoid leaving the plaintiff with an unjust result. ${ }^{106}$ When this happens, the jurors leave the courthouse with the feeling that the courts do not know how to administer justice. ${ }^{107}$ Finally, the doctrine is criticized because it is confusing and difficult to administer. ${ }^{108}$ Contributory negligence has several limitations that confuse jurors and are difficult to apply. ${ }^{109}$ As a result of these criticisms, forty-six states and many leading scholars have completely abandoned the doctrine. ${ }^{110}$

The movement away from contributory negligence was also recognized by

96. Treib v. Kern, 513 N.W.2d 908 (S.D. 1994). See also 57B AM. JUR. 2D Negligence § 806 (2004).

97. Treib, 513 N.W.2d. at 911.

98. Id.

99. Hatton v. Chem-Haulers, Inc., 393 So. 2 d 950, 954 (Ala. 1980) ("Contributory negligence requires a finding that the party charged has (1) knowledge of the condition; (2) an appreciation of the danger under the surrounding circumstances, and (3) a failure to exercise reasonable care by placing oneself in the way of danger."); see also 57B AM. JUR. 2D Negligence $§ 956$ (2004).

100. 57B AM. JUR. 2D Negligence § 799.

101. RESTATEMENT (THIRD) OF TORTS: Apportionment of Liability $\S 3 \mathrm{cmt}$ a (2000) ("[This Section of the Restatement] abolishes certain ameliorative doctrines that were designed to avoid the harsh effects of contributory negligence as an absolute bar to a plaintiff's recovery."); see also Gardner, supra note 86, at 1.

102. 57B AM. JUR. 2D Negligence § 801 (2004).

103. Mills v. Quality Supplier Trucking, Inc., 510 S.E.2d 280, 282 (W.V. 1998).

104. Gardner, supra note 87, at 31 .

105. Gardner, supra note 87, at 30-32.

106. Id.

107. Id.

108. Id. at 32 .

109. Id.

110. Id. at $36-38$ 
the American Law Institute ("A.L.I."). ${ }^{111}$ In the Restatement (Third) of Torts, the A.L.I. abolished the common law rule of contributory negligence and replaced it with the doctrine of comparative fault. ${ }^{112}$ While not mandatory authority, the A.L.I. recognizes the common law purpose behind the doctrine of contributory negligence and asserts that the purpose can be achieved without the doctrines unfair and harsh results. ${ }^{113}$ By advocating a movement toward the doctrine of comparative fault, the A.L.I. is using its highly persuasive authority to push the law to a more fair and just system as recognized by forty-six states.

\section{B. Comparative Fault}

Due to the unfairness ${ }^{114}$ imposed on plaintiffs by the doctrine of contributory negligence, many jurisdictions have adopted the doctrine of comparative fault. ${ }^{115}$ As a result, only four states and the District of Columbia maintain the (2000).

111. See Generally RESTATEMENT (THIRD) OF TORTS: Apportionment of Liability $\S \S 1-9$

112. RESTATEMENT (THIRD) OF TORTS: Apportionment of Liability $\S 3 \mathrm{cmt}$. a. (2000)

113. Id.

114. Gardner, supra note 87 , at 25 :

The primary criticism of the contributory negligence doctrine is nearly universal: The contributory negligence doctrine is inherently unfair. The doctrine makes one party bear the entire loss even though the loss is caused by the fault of two or more parties. Normally, the one party bearing the entire loss is the "injured plaintiff, least able to bear it, and quite possibly much less at fault than the defendant who goes scot free.

115. Id. at 36-38:

In 1910, Mississippi became the first state to adopt the comparative negligence doctrine generally when the Mississippi legislature enacted a pure comparative negligence statute. Between 1910 and 1968, six other states rejected the contributory negligence doctrine for some form of the comparative negligence doctrine. Beginning in 1969, the United States witnessed state after state reject the contributory negligence doctrine for the comparative negligence doctrine. Some of these states rejected the contributory negligence doctrine for the comparative negligence doctrine by statute. Others did so by a decision of the state's supreme court. Four states adopted comparative negligence in 1969, joined by one state in 1970, and four more states in 1971. The "stampede" had begun. Eleven states adopted comparative negligence in 1973, followed by one state in 1974, four states in 1975, one state in 1976, and three states in 1979. By the end of 1985 , nine more states had made the switch, bringing the number of states rejecting the contributory negligence doctrine for the comparative negligence doctrine to forty-four. In 1986, the contributory negligence roster included only six states: Alabama, Maryland, North Carolina, South Carolina, Tennessee, and Virginia. The South Carolina Supreme Court rejected contributory negligence for comparative negligence in 1991. The Tennessee Supreme Court followed suit in 1992. Today, the contributory negligence doctrine has been rejected by forty-six states. It is codified in federal negligence statutes, followed by the United States Supreme Court in admiralty suits, and pre- 
banner of the contributory negligence doctrine. ${ }^{116}$

The methods of adopting a comparative fault system have varied between jurisdictions. ${ }^{117}$ In some jurisdictions, comparative fault has been authorized by statute. ${ }^{118}$ Other states have adopted the system through judicial opinions. ${ }^{119}$ The adoption of a comparative fault system removes the negative effects of the "all or nothing" recovery rule imposed by the doctrine of contributory negligence. ${ }^{120}$ Instead, parties are now held liable for their part in causing the harm, allowing damages to be apportioned based on the percentage of fault assigned to each party. ${ }^{121}$ Like contributory negligence, comparative fault does not come into play in a case unless the trier of fact has established that both the plaintiff and the defendant were negligent in the resulting harm. ${ }^{122}$

While there are several types of comparative fault systems in the United States, the following are the most prevalent: ${ }^{123}$ "pure or $100 \%$ " comparative fault, ${ }^{124}$ "modified" comparative fault, ${ }^{125}$ and the "slight/gross" comparative negligence rule. ${ }^{126}$ Under the "pure or $100 \%$ " comparative fault system, damages are assessed proportionately based on each party's fault. ${ }^{127}$ For example, plaintiff sues defendant for negligence. The jury finds that the defendant was negligent and awards plaintiff $\$ 100,000$ in damages. The jury, however, also finds that the plaintiff was twenty percent at fault for the harm. Therefore, the plaintiff's damages are reduced by twenty percent, limiting his recovery to $\$ 80,000$ in damages. This school of thought is the most plaintiff-friendly application of the various comparative fault systems. Regardless of the amount of the plaintiff's fault, even if he is more at fault than the defendant, the plaintiff will recover the amount of damages less his percentage of fault. Under this system, the plaintiff's case cannot be defeated unless the defendant has proven that he was not negligent.

The second method is "modified" comparative fault. ${ }^{128}$ Under the "modified" comparative fault system, there are two schools of thought in applying the doctrine. ${ }^{129}$ The first holds that the plaintiff's negligence resulting in the harm must be less than the defendants. ${ }^{130}$ Under this rule, if the plaintiff's fault

vails in nearly all of the major civilized countries.

See also 57B AM. JUR. 2D Negligence 801(2004); 65 C.J.S. Negligence 291(2000).

116. 57B AM. JUR. 2D Negligence $\S 956$ (2004) (the four states that still use contributory negligence as a defense in negligence cases are Alabama, Maryland, North Carolina, Virginia).

117. Id. at $\S 957-58$.

118. Id. at $\S 957$.

119. Id. at $\S 958$.

120. Id. at $\S 955$.

121. Id.

122. 57B AM. JUR. 2D Negligence § 954 (2004).

123. Id. at $\S 961$.

124. Id.

125. Id.

126. Id. at $\S 698$..

127. Id. at $\S 962$.

128. 57B AM. JUR. 2D Negligence $\S 962$ (2004).

129. Id.

130. Id. 
is an equal or greater force in causing the harm, he is barred from recovery. ${ }^{131}$ For example, if a jury finds that a defendant is negligent and awards $\$ 100,000$ in damages, it will proceed to the next step and analyze the plaintiff's conduct. If the jury finds that the plaintiff's conduct was fifty percent at fault for causing the harm, the plaintiff is barred from recovery because his negligence was not less than that of the defendant. Conversely, if the jury finds that the plaintiff's actions were forty-nine percent responsible for causing the harm, he would recover damages minus the proportion of his fault. Therefore, the plaintiff would recover $\$ 51,000$ from the defendant.

The second school of thought requires that the plaintiff's negligence resulting in the harm must not be greater than the defendant's negligence. ${ }^{132} \mathrm{Un}$ der this application of the doctrine, the plaintiff may recover as long as his percentage of fault is not greater than that of the defendant. In a jurisdiction that applies this doctrine, the jury could find that the plaintiff and defendant were equally at fault and thus award the plaintiff half the damages received from the defendant. ${ }^{133}$ Turning back to the above example, under this approach the jury finds that the plaintiff was fifty percent at fault for the harm. In this scenario, the plaintiff would still recover $\$ 50,000$ from the defendant for his portion of the harm. Even though the plaintiff was just as responsible for the harm, he is not barred from recovery. If the jury finds the plaintiff fifty-one percent at fault, this approach would bar any recovery. Thus the "modified" comparative fault system works to prevent a plaintiff from recovering for the harm they caused themselves, and at the same time does not bar recovery if a majority of the fault causing the harm rests with the defendant.

The final system is the "slight/gross" comparative negligence rule. ${ }^{134}$ The "slight/gross" method of comparative fault is used to "render the rule of contributory negligence inapplicable if the contributory negligence of the plaintiff is small" compared to that of the defendant. ${ }^{135}$ There is no absolute basis for determining whether the negligence of the plaintiff was slight or gross. ${ }^{136}$ This method is based solely on the objective, or reasonable person, standard of negligence. ${ }^{137}$ The application of the "slight/gross" rule entitles a defendant to a judgment in their favor if the defendant can prove that the plaintiff's contribution was more than slight and the defendant's negligence was not gross when compared to the plaintiff's conduct. ${ }^{138}$ The down side to this application of comparative fault is that there is no definitive rule on how to compare the negligence of the two parties. ${ }^{139}$ This method relies entirely on a case-by-case re-

131. Id. at $\S 965$.

132. Id.

133. Id. at $\S 966$.

134. 57B AM. JUR. 2D Negligence $§ 968$ (2004).

135. Id. at $\S 969$.

136. Id. at $\S 970$.

137. Id. at $\S 970$.

138. Id. at $\S 968$.

139. Id. at $\S 971$. 
view of the facts. ${ }^{140}$ Thus, similar facts that exist between two separate cases can result in vastly different outcomes.

\section{Comparative Fault in Indiana}

Indiana does not ascribe to the harsh and unjust doctrine of contributory negligence. In fact, Indiana would proudly point to the fact that they are a comparative fault state in line with an overwhelming majority of states in the Union. This is shown through the Indiana Comparative Fault Act ("CFA"). 141

\section{Legislative History of the Comparative Fault Act}

Passage of the CFA began in $1973 .{ }^{142}$ The first attempt to bring Indiana into the comparative fault system, however, failed. ${ }^{143}$ Two separate bills were introduced, but neither bill made it out of the House Judiciary Committee. ${ }^{144}$ In 1981, legislation, based on the 1977 Uniform Comparative Fault Act, was introduced. ${ }^{145}$ The 1981 bill proposed the introduction of a pure comparative fault system. ${ }^{146}$ The 1981 bill was strongly opposed by lobbyists, particularly from the insurance industry. ${ }^{147}$ As a result of the strong and influential lobbing effort, the 1981 bill was defeated in committee. ${ }^{148}$

In 1983, a new comparative fault bill was introduced to the Indiana General Assembly that proposed a "modified" comparative fault system. ${ }^{149}$ Under this system, defendants to tort claims would no longer benefit from the complete affirmative defense of contributory negligence. ${ }^{150}$ At the same time, plaintiffs in tort actions would no longer be subjected to the harsh penalty of no recovery for their contributory negligence. Instead, under the proposed system, a plaintiff would recover damages if his contributory negligence was not greater than that of the defendant. ${ }^{151}$ If the plaintiff's negligence in causing the harm was greater than the defendants, the plaintiff's recovery would be completely barred. ${ }^{152}$ The 1983 bill was the perfect blend of the contributory negligent

140. 57B AM. JUR. 2D Negligence $\S 971$ (2004).

141. IND. CODE § 34-51-2-1 (2006).

142. Edgar W. Bayliff, Drafting and Legislative History of the Comparative Fault Act. 17 IND. L. REV. 863, 863 (1984).

143. Id.

144. $I d$.

145. Id.

146. Id.

147. Id.

148. Bayliff, supra note 142.

149. Id.

150. Lawrence P. Wilkins, The Indiana Comparative Fault Act at First (Lingering) Glance. 17 IND. L. REV. 687, 687 (1984).

151. Id. ("[A] plaintiff whose conduct satisfies the statutory definition of "fault" will be entitled to recover damages reduced in proportion to that fault.").

152. Id.:

If the plaintiff's fault is assessed at greater than $50 \% \ldots$ recovery will be to- 
principle of not rewarding someone for their own negligence while at the same time removing the harshness of a complete bar of recovery. This bill was introduced to both houses where it passed by a large majority vote in each house. ${ }^{153}$ The bill was sent to Governor Robert Orr, who ratified the bill on April 21, 1983. ${ }^{154}$ Comparative fault in Indiana went into effect on January 1, 1985. ${ }^{155}$ Under this legislation, Indiana adopted the comparative fault in its modified form, barring a plaintiff's recovery when he is more at fault than the defendant. ${ }^{156}$ While there was a comparative fault act in place, it was not true comparative fault across the board.

\section{A Huge Comparative Fault Exception}

While the principles of contributory negligence are still present under the $\mathrm{CFA}^{157}$ there is still one group ${ }^{158}$ of plaintiffs which must face the cruelties of the contributory negligence defense. The CFA has two provisions that affect medical malpractice cases. First, the CFA specifically exempts cases of medical malpractice against qualified health care providers. ${ }^{159}$ The Indiana Supreme Court has clarified this by exempting qualified heath care providers from the CFA-the legislature intended the common law defense of contributory negli-

tally barred. The Indiana Comparative Fault Act is...not a complete acceptance of the comparative fault principle because the common law tory negligence bar continues to operate for some injured plaintiffs who are not wholly responsible for their injuries.

153. Bayliff, supra note 139, at 865-66. (The original bill, Senate Bill 331, was passed in the Senate by a 34-15 vote. Senate Bill 331 was then sent to the House where it was met with a strong resistance and fears that it would cost the state millions of dollars. Subsequently, the deadline for the house to approve Senate bills passed, and the only way the comparative fault bill would be enacted was to strip a bill that had already passed and add the language of S.B. 331 to it. Fortunately for the Comparative Fault Act, Kokomo Senator James Butcher sacrificed his bill, S.B. 287, dealing with the distribution of trust assets, for the comparative fault bill. The language of 331 was substituted in 287 . The new substituted bill was approved by the Senate 41 to 6 and the house 78 to 12 .).

154. Id. at 866 .

155. Id.

156. IND. CODE 34-51-2-6 (2006).

157. 57B AM. JUR. 2D Negligence § 961(2004).

158. The CFA exempts Government entities from its provisions. Thus, any plaintiff bringing a negligence suit against a governmental body within the State must face the contributory negligence defense and bare its force should that be found to have contributed to their injuries. Government entities, however, are beyond the scope of this Note. See generally IND. CODE $\S$ 34-51-2-2 (2006).

159. IND. CODE § 34-51-2-1 (2006):

(a) This chapter governs any action based on fault that is brought to recover damages for injury or death to a person or harm to property, except as provided in subsection (b).

(b) This chapter does not apply to an action:

(1) brought against a qualified health care provider under IC 16-9.5 (before its repeal), IC 27-12 (before its repeal), or IC 34-18 for medical malpractice. 
gence to be available to this class of defendants. ${ }^{160}$ With this doctrine, plaintiffpatients in a medical malpractice suit may still be barred from recovery if the court finds that they contributed to their own injury, regardless of how slight their apportionment of fault may be. ${ }^{161}$ The reality of this law is that a plaintiff may be barred from complete recovery for simply failing to take a prescribed medication one time as instructed. ${ }^{162}$

The second aspect of the CFA is that it provides a process to combine cases that involve both qualified and unqualified health care providers. ${ }^{163} \mathrm{Un}$ der the MMA, claims against a qualified provider are required to go before a Panel. When both qualified and unqualified health care professionals commit an act of medical malpractice under the MMA it is possible for the unqualified providers' case to go to trial before the Panel completes its review of the case against the qualified provider. ${ }^{164}$ The CFA addresses and alleviates this problem. ${ }^{165}$ It gives the court the authority to "grant reasonable delays" to allow the Panel to complete its evaluation of the case against the qualified defendant(s). ${ }^{166}$ Once the Panel has completed its evaluation, rendered a decision, and an action can be brought against the qualified defendant, the court must then allow joinder of the qualified defendant before the suit can proceed. ${ }^{167}$ This section of the CFA bestows two benefits on the plaintiff-patient. ${ }^{168}$ First, it prevents the plaintiff from enduring two separate trials based on the same fact pattern. ${ }^{169}$ Second, it prevents the defendant-physicians from using the "empty chair" defense and pointing the finger at a non-party to shift blame. ${ }^{170}$ While these are huge benefits for the plaintiff, these provisions do not prevent the plaintiff-patient from the prospect of facing the contributory negligence defense

160. Cavens, 849 N.E.2d at 529.

161. Id.

162. Id.; see also Harris v. Cacdac, 512 N.E.2d 1138, 1141 (Ind. Ct. App. 1987).

163. IND. CODE § 34-51-2-18 (2006).

164. Wilkins, supra note 150 , at 739 .

165. Id.

166. IND. CODE § 34-51-2-18 (2006).

This section applies to an action based on fault that is brought by the claimant against: (1) one (1) or more defendants who are qualified health care providers under IC 34-18; and (2) one (1) or more defendants who are not qualified health care providers. (b) Upon application of the claimant, the trial court shall grant reasonable delays in the action brought against those defendants who are not qualified health care providers until the medical review panel procedure can be completed as to the qualified health care providers."

See also Wilkins, supra note 150 , at 740 .

167. IND. CODE $\S 34-51-2-18$ (c) (2006). ("When an action is permitted to be filed against the qualified health care providers, the trial court shall permit a joinder of the qualified health care providers as additional defendants in the action on file against the nonhealth care providers.").

168. Wilkins, supra note 150 , at 740 .

169. Id.

170. Id. 
and thus the prospect of being denied recovery altogether.

\section{THE STATE OF HEALTh CARE IN THE UNITED STATES: EXAMINATION OF MEDICAL MALPRACTICE LEGISLATION IN OTHER STABLE STATES}

With the skyrocketing cost of health care, all states have taken action and adopted tort reform statutes. ${ }^{171}$ The effectiveness of these reforms, however, has varied from state to state. ${ }^{172}$ According to the American Medical Association ("AMA"), eighty-six percent of the states (including the District of Columbia) are in or on the borderline of a medical liability crisis. ${ }^{173}$ Only eight states are currently on stable ground with their health care systems, ${ }^{174}$ including Indiana. ${ }^{175}$ Arguably, Indiana's stable health care environment is due to the comprehensive medical tort reform legislation enacted in 1975, as Indiana was the first state to pass such a comprehensive health care reform and its legislation served as a model for other states to follow. ${ }^{176}$

California has taken steps to keep the cost of health care down and avoid another health care crisis. California allows Medical Malpractice actions to be brought in court provided that the health care professional is given a ninety day notice of the action. ${ }^{177}$ There are no unusual notice requirements, and failure to meet the notice requirement does not kill the action. ${ }^{178}$ In fact, the only effect of failure to comply with notice is possible sanctions against a plaintiff's attorney. ${ }^{179}$ A second measure taken by the California state legislature was the limitation of non-economic damages in actions against health care providers. ${ }^{180}$ In medical malpractice actions, the statutory limit on non-economic damages is $\$ 250,000$. $^{181}$ A third step taken by California was to impose a statute of limitations on all medical malpractice claims. ${ }^{182}$ In California, an injured patient has three years from the date of injury or one year after date of discovery, whichever is longer, to file suit. ${ }^{183}$ Finally, California is a comparative fault state, ${ }^{184}$ as

171. Westlaw 50 State Survey. Health Care: Medical Malpractice, Tort Reform. (West 2008) (showing all 50 state and the District of Columbia have passed medical malpractice tort reform.).

172. American Medical Association, "Medical Liability Crisis Map," AMA NEws AND INFORMATION, (January 2007), available at http://www.wisconsinmedicalsociety.org/_WMS/ communication/press_release/med_liab_jan07.pdf.

173. Id. (According to the AMA, seventeen states are currently facing a health care crisis. Twenty-six states are teetering on the edge of a crisis and eight states are stable.)

174. Id. (The eight stable states are: California, Colorado, Idaho, Indiana, Louisiana, New Mexico, Texas, and Wisconsin.).

175. Id.

176. Kinney, supra note 2 , at 169.

177. Cal. Crv. Proc. Code $\S 364$ (West 2006).

178. Cal. Civ. Proc. Code $\S 365$ (West 2006).

179. Id.

180. CAL. CIV. CODE $§ 3333.2$ (West 1997).

181. Id.

182. Cal. Civ. Proc. Code $\S 340.5$ (West 2006).

183. Id. 
it has adopted the doctrine of comparative fault judicially. ${ }^{185}$ The system adopted, however, was a pure comparative fault. ${ }^{186}$ Under this framework, a party can always recover damages in an action for any percentage of injury which were not caused by his own fault. ${ }^{187}$

Colorado is another state on the AMA's stable list. In 1988, the Colorado state legislature recognized the importance of continued availability and access to health care for its citizens. ${ }^{188}$ The Colorado state legislature enacted medical malpractice tort reform by passing the Health Care Availability Act ("Liability Act"). ${ }^{189}$ The "Liability Act" provides a $\$ 300,000$ damages cap on punitive damages against a defendant-physician in medical malpractice actions effective July $1,2003 .{ }^{190}$ Colorado, however, has not capped damages awarded for economic loss. ${ }^{191}$ The state implemented procedural requirements to control judgments calling for high economic loss values. ${ }^{192}$ When a court enters a judgment for economic loss damages, it must order that the damages be paid out through periodic payments when the damages awarded are greater than $\$ 150,000 .{ }^{193}$ When the trier of fact awards economic loss damages, it must make specialized separate findings for each claim, specifying ${ }^{194}$ "any past damages"195 and "any future damages and the period of time over which they will be paid."196 The

184. See Li v. Yellow Cab Co. of California, 532 P.2d 1226 (Cal. 1975).

185. Id. at 1247.

186. Id. at 1242 .

187. 57B AM. JUR. 2D Negligence § 961(2004).

188. Colo. Rev. Stat. ANN. § 13-64-102 (West 2005).

189. Id. at 13-64-101 to -503 (West 2005).

190. Id. at $\S 13-64-302$ (West 2005).

191. Id. at $\S 13-21-102.5$ (West 2005).

The general assembly finds, determines, and declares that awards in civil actions for noneconomic losses or injuries often unduly burden the economic, commercial, and personal welfare of persons in this state; therefore, for the protection of the public peace, health, and welfare, the general assembly enacts this section placing monetary limitations on such damages for noneconomic losses or injuries.

192. Id. at $\S 13-64-203$ to -204 .

193. Id. at $\S 13-64-203$.

In any civil action for damages in tort brought against a health care professional or a health care institution, the trial judge shall enter a judgment ordering that awards for future damages be paid by periodic payments rather than by a lump-sum payment if the award for future damages exceeds the present value of one hundred fifty thousand dollars, as determined by the court. (2) In any such action in which the award for future damages is one hundred fifty thousand dollars or less, present value, the trial judge may order that awards for future damages be paid by periodic payments.

194. Colo. Rev. Stat. ANN. § 13-64-204 (West 2004).

195. Id. at $\S 13-21-204$ (a) (The type of past damages that the jury can award for are "(I) Medical and other costs of health care; (II) Other economic loss except loss of earnings; (III) Loss of earnings; and (IV) Noneconomic loss.")

196. Id. at $\S 13-64-204$ (b) (The types of future damages for which the trier of fact my award for are: (I) Medical and other costs of health care; (II) Other economic loss except loss of future earnings which would be incurred for the life of the claimant or any lesser period; (III) Loss of future earnings which would be incurred for the work life expectancy of the claimant or 
Colorado statute, however, does not require that the case be reviewed by a Panel nor does it mandate a shortened statute of limitations period. ${ }^{197}$ Finally, Colorado is a comparative fault state, ${ }^{198}$ using a modified comparative fault doctrine which bars recovery only if the plaintiff's negligence is as great as or greater than the negligence of the defendant. ${ }^{199}$ The Colorado comparative fault statute does not carve out an exception for health care professionals. ${ }^{200}$

Louisiana also enjoys a stable health care environment and has adopted extensive medical malpractice legislation. ${ }^{201}$ Louisiana requires that all medical malpractice claims be reviewed by a Panel, administered as a binding arbitration procedure, prior to being litigated in a court of law. ${ }^{202}$ The composition of the Panel is the same as the boards formed in Indiana: one attorney ${ }^{203}$ who serves as the chairperson ${ }^{204}$ and three medical doctors. ${ }^{205}$ The physicianmembers sitting on the Panel must have unrestricted licenses to practice in the state. ${ }^{206}$ If the defendant specializes in a particular field of medicine, then two of the physicians on the Panel must practice in the same specialized field. ${ }^{207}$ The sole duty of the Panel is to render an expert opinion based on all the evidence and state whether or not the defendant-physician did or did not meet the appropriate standard of care under the circumstances. ${ }^{208}$ Once the expert opi-

a lesser period; and (IV) Noneconomic loss which would be incurred for the life of the claimant or any lesser period.).

197. See generally CoLo. Rev. STAT. ANN. § 13-64 (West 2004).

198. Id. at $\S 13-21-111$.

199. Id. at § 13-21-111(1):

Contributory negligence shall not bar recovery in any action by any person or his legal representative to recover damages for negligence resulting in death or in injury to person or property, if such negligence was not as great as the negligence of the person against whom recovery is sought, but any damages allowed shall be diminished in proportion to the amount of negligence attributable to the person for whose injury, damage, or death recov-

200. Id. ery is made.

201. LA. REV. Stat. ANN. $\S \S 40: 1299.41-.49$ (2001).

202. LA. REv. STAT. ANN. § 40:1299.47 (2001 \& Supp. 2007).

203. Id. at $\S 40: 1299.47(\mathrm{C})$.

204. Id. at $\S 40: 1299.47(\mathrm{C})(2)$.

205. Id. at $\S 40: 1299.47(\mathrm{C})$.

206. Id. at $\S 40: 1299.47(\mathrm{C})(3)(\mathrm{f})$.

207. Id. at $\S 40: 1299.47(C)(3)(\mathrm{j})$.

208. LA. REV. STAT. ANN. $\S 40: 1299.47(G)$. The Panel is required to render one or more of the following three opinions:

(1) The evidence supports the conclusion that the defendant or defendants failed to comply with the appropriate standard of care as charged in the complaint.

(2) The evidence does not support the conclusion that the defendant or defendants failed to meet the applicable standard of care as charged in the complaint. (3) That there is a material issue of fact, not requiring expert opinion, bearing on liability for consideration by the court. (4) When Paragraph (1) of this subsection is answered in the affirmative, that the conduct complained of was or was not a factor of the resultant damages. If such conduct was a factor, whether the plaintiff suffered: (a) any disability and 
nion is rendered, it is admissible in court as expert testimony. ${ }^{209}$

The Louisiana state legislature has also created a PCF to be used to compensate plaintiffs for injuries received in a medical malpractice claim. ${ }^{210}$ Funds for the PCF are raised by placing a surcharge on all qualified providers practicing in the state. ${ }^{211}$ The Louisiana law, much like the Indiana statute, gives the commissioner who oversees the fund wide latitude to use and protect the monies in the fund. ${ }^{212}$

Louisiana has also placed a cap of $\$ 500,000$ on non-economic damages. ${ }^{213}$ As in the Indiana MMA, Louisiana's law requires the physician to be a qualified provider as determined by financial responsibility for the cap on noneconomic damages to apply. ${ }^{214}$ Louisiana, however, does not place a cap on economic damages. ${ }^{215}$ For the jury to determine that the plaintiff qualifies for "future medical expenses and related benefits," ${ }^{216}$ the jury must be given a special interrogatory to determine the plaintiff's need for "future medical expenses and related benefits." ${ }^{217}$ There has been a constitutional challenge to the noneconomic damages provision of the Louisiana Act. ${ }^{218}$ The Louisiana Court of Appeals has held that the damage cap provision of the Louisiana Act is uncons-

the extent and duration of the disability, and (b) any permanent impairment and the percentage of the impairment.

209. Id. at. $\S 40: 1299.47(\mathrm{H})$.

210. Id. at $\S 40: 1299.44$ (2001 \& Supp. 2007).

211. Id. at $\S 40: 1299.44 \mathrm{~A}(2)(\mathrm{a})$.

212. Id. at $\S 40: 1299.44 \mathrm{~A}(5)(\mathrm{a})$.

213. LA. REV. STAT. ANN. § 1299.42(b)(1) (2001).

214. Id. at $\S 1299.42(\mathrm{D})$.

A health care provider who fails to qualify under this Part is not covered by the provisions of this Part and is subject to liability under the law without regard to the provisions of this Part. If a health care provider does not so qualify, the patient's remedy will not be affected by the terms and provisions of this Part, except as hereinafter provided with respect to the suspension and the running of prescription of actions against a health care provider who has not qualified under this Part when a claim has been filed against the health care provider for review under this Part.

215. Id. at $\S 40: 1299.43$.

216. Id. at $\S 40: 1299.43(\mathrm{~B})$ :

1) "Future medical care and related benefits" for the purpose of this Section means all of the following: (a) All reasonable medical, surgical, hospitalization, physical rehabilitation, and custodial services and includes drugs, prosthetic devices, and other similar materials reasonably necessary in the provision of such services, incurred after the date of the injury up to the date of the settlement, judgment, or arbitration award. (b) All reasonable medical, surgical, hospitalization, physical rehabilitation, and custodial services and includes drugs, prosthetic devices, and other similar materials reasonably necessary in the provisions of such services, after the date of the injury that will be incurred after the date of the settlement, judgment, or arbitration award. (2) "Future medical care and benefits" as used in this Section shall not be construed to mean non-essential specialty items or devices of convenience.

217. Id. at $\S 40: 1299.43(\mathrm{~A})(1)$.

218. See Arrington v. ER Physicians Group, 940 So.2d 777 (La. Ct. App. 2006). 
titutional. $^{219}$ The status of the law, however, is still in question as the Louisiana Supreme Court has vacated the Louisiana Court of Appeals decision and remanded the case for further findings. ${ }^{220}$

Like the majority of jurisdictions, Louisiana is a comparative fault state $\mathrm{e}^{221}$ and has statutorily established a doctrine of "pure" comparative fault ${ }^{222}$ for the sole purpose of preventing the harsh results indicative of the contributory negligence doctrine. ${ }^{23}$ By adopting comparative fault in its pure form, Louisiana allows damages to be apportioned between both parties of an action when both are negligent in causing the litigated harm. ${ }^{224}$ The pure system of comparative fault is much friendlier to the plaintiff than either of the modified forms of the doctrine. Under the pure system, a plaintiff's damages can be reduced to compensate for the plaintiff's own negligence. ${ }^{225}$ This is a major benefit for the plaintiff because it ensures that the plaintiff's claim will not be completely defeated even if the majority of responsibility for the injury lies with the plaintiff himself. $^{226}$

Four other states-Idaho, New Mexico, Texas, and Wisconsin-are enjoying a stable health care environment and have followed the same pattern as the four preceding states. All four states have passed medical malpractice legislation. ${ }^{227}$ While the individual statutes may differ slightly, there are a few noticeable similarities between these states' methods of dealing with medical malpractice cases. First, all four states have a statute of limitations addressing when medical malpractice actions may be brought against a provider. ${ }^{228}$ Second, all the states have special procedural requirements placed on actions for medical malpractice. ${ }^{229}$ These special procedures include the requirement for a case review by a Panel, ${ }^{230}$ special expert reports from both parties to be

219. Id.

220. See Arrington v. Galen-Med, Inc., 947 So.2d 719 (La. 2007).

221. LA. Rev. Stat. ANN. Art. 2323 (1997).

222. Id.

223. Watson v. State Farm Fire \& Cas. Ins. Co, 469 So.2d 967, 971 (La. 1985) (“A pure comparative fault system was adopted in Louisiana in 1979 by Act No. 431 . That act became effective only on August 1,1980 . It was specifically designed to ameliorate the harshness of the contributory negligence doctrine...").

224. Id.

225. Id. at $971 \mathrm{fn} .9$.

226. Id. ("Under the pure comparative fault system, adopted by the Louisiana legislature in 1980 , plaintiff's negligence will only diminish, not defeat, recovery as long as plaintiff's negligence is less than $100 \% . ")$.

227. See IDAHo CodE ANN. §§ 6-1001 to -1013 (2006), N.M. STAT. ANN. §§ 41-5-1 to -29 (West 1996), TeX. Civ. Prac. \& ReM. Code ANN. $§ ~ 74.001-507$ (Vernon 2005), and Wis. STAT. ANN. $\S \S 655.001-.68$ (West 2004).

228. See Idaho Code ANN. $\$ 5-219$ (2006), N.M. Stat. ANN. $\$ 41-5-13$ (West 1996), TeX. Civ. PRAC. \& REM. CODE ANN. § 74.251(Vernon 2005 and Supp. 2007.) and WIS. STAT. ANN. 893.55 (West 1997).

229. See IDAHo Code ANN. $\S \S 6-1001$ to -1013 (West 2006), N.M. STAT. ANN. § 41-5-14 (West 1996), TeX. Civ. Prac. \& ReM. Code ANN. § 74.351(Vernon 2005), and Wis. Stat. ANN. $\S \S 655.42-.61$ (West 2004).

230. See IdAHo CODE ANN. $\S \S 6-1001$ (2006) and N.M. Stat. ANN. $\S ~ 41-5-14$ (West 
produced in a specific period of time, ${ }^{231}$ and a requirement for mediation. ${ }^{232}$ Third, each state, with the exception of Idaho, places a cap on damages. ${ }^{233}$ Finally, in addition to the states having passed medical malpractice legislation, all four states are comparative fault states. ${ }^{234}$ None of the states create an exception for medical malpractice cases, subjecting plaintiffs injured by health care providers to the harsh results of the contributory negligence doctrine.

\section{INDIANA SHOULD ABOLISH THE DOCTRINE OF CONTRIBUTORY NEGLIGENCE IN MEDICAL MALPRACTICE CASES}

\section{A. The Effectiveness of the Indiana Medical Malpractice Act}

Indiana should allow its modified doctrine of comparative fault to include cases claiming medical malpractice. Application of the doctrine of contributory negligence is excessive when used in conjunction with the MMA. The MMA sets out many limitations and procedural requirements including the shortened statute of limitations that are designed to insulate the medical profession from frivolous lawsuits and large judgments or settlements. ${ }^{235}$ The statute of limitations serves to prevent old, stale lawsuits from being filed against a physician when the facts, records, and witnesses' memories of the case have become clouded by the element of time. ${ }^{236}$

Along with the shortened statute of limitations, the MMA requires all medical malpractice claims against qualified providers be submitted to the Panel process. ${ }^{237}$ The Panel then reviews the case and renders an expert opinion. By requiring Panel review, the parties get a sense of the strength of their case which works to promote settlement. The only foreseeable complication to this process occurs when there is a complaint filed simultaneously against both a qualified and a non-qualified physician. Should this circumstance arise, however, the CFA effectively deals with it by giving the trial court the power to grant "reasonable delays" in order to give the Panel time to complete its review against the qualified provider(s). ${ }^{238}$

Finally, the MMA places the hard cap on all damages in medical malpractice cases. ${ }^{239}$ Both economic and non-economic damages are capped at $\$ 1.25$

1996).

231. Tex. Code ANN. § 74.351(Vernon 2005 and Supp. 2007).

232. Wis. STAT. ANN. $\S \S 655.42$ (West 2004).

233. See N.M. Stat. ANN. § 41-5-6 (West 1996) (limiting economic damages), Tex. Civ. PRAC. \& REM. CODE ANN. § 74.301 (West 2005) (limiting non-economic damages), and Wis. STAT. ANN. 893.55 (West 1997) (limiting non-economic damages).

234. See Idaho Code AnN. § 6-802 (West 2005), Tex. Civ. Prac. \& Rem. Code AnN. § 33.001-002(West 1997), Wis. Stat. ANN. 895.045 (West 2006), and Scott v. Rizzo, 634 P.2d 1234 (N.M., 1981).

235. IND. CODE § 34-18-7-1 (2006).

236. IND. CODE § 34-18-7-1 (2006).

237. IND. CODE § 34-18-8-4 (2006).

238. IND. CODE $\S 34-51-2-18$ (a) - (b) (2006). See also Wilkins, supra note 147, at 740 .

239. IND. CODE § 34-18-14-3 (2006). 
million. ${ }^{240}$ This provision is in stark contrast to the other stable states discussed in this Note. Indiana is the only one of the eight states that places a limit on economic damages. Thus, in all cases filed against a qualified physician, the maximum possible recovery is already known and worked into the medical malpractice liability insurance agreement. All of these protections combine to insure that the cost of medical malpractice insurance will not cause professional liability insurance to sky rocket. They also insure that health care costs will remain reasonable for all Hoosiers. Therefore, retaining the doctrine of contributory negligence serves no function in keeping Indiana out of a health care crisis.

\section{B. Contributory Negligence is Unfair, Harsh, and Ineffective}

The Indiana state legislature was well aware of the harsh and often unfair results that were at the heart of the doctrine of contributory negligence. This was evident by the fact that seven years after enacting the MMA, Indiana changed its law to conform to the majority of states by adopting comparative fault. $^{241}$ When the MMA was originally passed in 1976, Indiana had a system in place that recognized contributory negligence in all tort cases based on a theory of negligence. ${ }^{242}$ Currently, Indiana has abolished the doctrine in all but two areas of tort law: suits against Government entities and medical malpractice claims. ${ }^{243}$ In the area of medical malpractice, the doctrine does not lead to just results. By maintaining the doctrine of contributory negligence, Indiana essentially gives a defendant-health care providers the ability to completely escape liability when they are, for all intensive purposes, negligent and deserving of reprimand. The doctrine of contributory negligence also creates a disincentive for settling the case. Should a defendant believe that the plaintiff has any fault in the harm, the availability of the contributory negligence defense creates an incentive for the physician to take the matter to trial. The physician also has less of an incentive to end the case quickly with a settlement. He can take a firm attitude and refuse any reasonable settlement terms that the plaintiff may propose. As a result of this "escape clause," both parties may be forced to endure a lengthy trial and waste the courts' resources in a case where the defendant is obviously guilty of medical malpractice. The irony of it all is the fact that the MMA was passed to insure that all citizens of Indiana would continue to receive quality health care. Yet, the State grants a physician an "escape

240. IND. CODE § 34-18-14-3 (2006).

241. Gardner, supra note 87 (showing that from 1910, when the first state recognized comparative fault to 1979 , thirty five states and the District of Columbia changed their laws, either judicially or statutorily, to recognize the doctrine of comparative fault as a defense in negligence suits.)

242. Solonosky v. Goodwell, 892 N.E.2d 174, 185 (Ind. Ct. App. 2008) (stating that the primary purpose of the [Indiana Comparative Fault] Act was to Modify the common law rule of contributory negligence...).

243. IND. CODE 34-51-2-2 (2006). 
clause" and bars the patient from recovery when the provider fails to deliver quality health care. The entire process of maintaining contributory negligence in medical malpractice cases is counter-intuitive to the purpose of the MMA. There is also no evidence that maintaining a contributory negligence scheme helps to ensure that the costs of health care and medical liability insurance premiums remain low.

\section{Comparing Indiana to Other States Enjoying a Stable Health Care Environment}

The major argument against the adoption of comparative fault in medical malpractice cases is that it will subject providers to more liability and thereby cause Indiana to spin into another health care crisis. There is no evidence, however, that applying the doctrine of contributory negligence to medical malpractice cases has kept Indiana out of a health care crisis. The evidence suggests that whether a state is a contributory negligence state or a comparative fault state has no bearing on the stability of its health care environment. ${ }^{244}$ As can be seen by comparing the eight stable states side by side, Indiana stands alone in applying the doctrine of contributory negligence to medical malpractice cases, while the other states apply a form of comparative fault to such cases. ${ }^{245}$ Furthermore, it does not appear that the form of comparative fault applied affects the stability of the health care environment. The evidence shows that the defenses available to a defendant-physician are not a component in creating a stable health care environment.

The strongest evidence for achieving a stable health care environment is taking some type of legislative action that directly addresses medical malpractice cases and provides some limitations. Arguably, the most effective way to ensure health care stability is by capping damages at a modest level. In fact, of the eight states that have a stable health care environment, Idaho is the only state that does not place a cap on any damages. ${ }^{246}$ Four of the remaining eight states cap non-economic or punitive damages but allow the court to award full economic damages. ${ }^{247}$ One state caps non-economic damages and places a hybrid form of economic damages by allowing the plaintiff to recover for medical and other related expenses. ${ }^{248}$ The final state places a cap on economic damages. $^{249}$ Indiana places a cap on both economic and non-economic damages. ${ }^{250}$ This makes Indiana the most stable system because the maximum award for

244. See supra Section IV 31-40.

245. See supra Section IV 31-40.

246. See supra Section IV 31-40.

247. Cal. Crv. $\S 3333.2$ (West 1997), Colo. Rev. Stat. ANN. $\S 13-64-302$ (West 2005),

Tex. Civ. Prac. \& Rem. Code ANN. § 74.301 (Vernon 2005), and Wis. Stat. AnN. 893.55 (West 2004).

248. LA. Rev. Stat. ANN. $§ 1299.42$ (b)(1) (2001).

249. N.M. STAT. ANN. § 41-5-6 (West 1996).

250. IND. CODE § 34-18-14-3 (2006). 
damages is already pre-determined. The other states still have uncertainty of how great the damages awarded will truly be when the economic damages are calculated.

Another similar aspect is the special procedural requirement that the states place on medical malpractice cases. Whether it is advanced notice statutes, peer review boards, or requirements mandating mediation, all of the proposed requirements help to promote settlement between the parties. It is commonly believed that a health care provider who receives a negative opinion from a Panel would be more likely to settle with the plaintiff rather than face a potentially lengthy trial and publicity inherent with the same. Similarly, advanced notice statutes give the defendant advanced warning to allow him to evaluate the case and propose a settlement to the complaining party. The gist of these procedural requirements is to help the parties to avoid the expense of litigation. By avoiding the litigation, the cost to health care providers and their insurers is decreased and thereby the cost of health care is kept under control for the states' respective citizens.

\section{The Effect of Adopting the Doctrine of Comparative Fault in the Modified Form on Health Care in Indiana}

If the other stable states are any gauge on the effects of applying comparative fault in medical malpractice cases, adopting comparative fault in Indiana will not affect the health care environment in the state. Indiana has already adopted a modified comparative fault system for all tort cases except in lawsuits against health care entities and governmental bodies. ${ }^{251}$ Under the Indiana system, the plaintiff does not recover damages when his fault is apportioned greater than fifty percent. ${ }^{252}$ This application still provides a substantial obstacle and bars recovery when the plaintiff is more responsible than the provider for the harm, thereby giving the physician a formidable defense tactic. Conversely, when a patient is not more at fault than the provider, he can recover from the provider for his allocation of responsibility in causing the injury and is not completely barred from recovery for an injury that results from a physician's negligence. ${ }^{253}$ This type of result is more fair and upholds the principle of not rewarding a plaintiff who was more responsible for his own injuries than the defendant. Thus, adoption of this method would not be against the intent of the legislature when it adopted the MMA. Rather, the more equitable system of modified comparative fault would be closer to the legislature's intent of insuring quality health care for all Hoosiers.

Finally, with all the layers of protection inherent in the MMA, the adoption of comparative fault would not place health care providers in a worse posi- 
tion and subject them to more liability. As discussed previously, Indiana has more safeguards built into its MMA than the other seven "stable" states. Those safeguards, not the doctrine of contributory negligence, are what have created a stable health care environment. In fact, according to the AMA, the four states ${ }^{254}$ that still adhere to the doctrine of contributory negligence in their tort law are facing or are on the brink of facing a health care crisis. ${ }^{255}$ Whether or not a state uses comparative fault or contributory negligence as a defense against a medical malpractice action has no bearing on preventing a health care crisis, neither does the use of a particular form of comparative fault. Therefore, the only functions served by keeping the doctrine of contributory negligence in medical malpractice actions in Indiana is to place yet another barrier in front of wronged patients and create a potential windfall for a negligent physician, thereby allowing him to escape unscathed for his wrongful conduct. That is not, and cannot ever be, a fair system which works to promote quality healthcare in Indiana.

\section{E. How Does the Law Get Changed?}

Indiana has a statutory provision that carves out an exception for medical malpractice cases from the CFA. The state courts have been very reluctant, and maybe rightfully so, to overrule the state legislature when it comes to the issue of health care. Thus, it is unlikely that the courts of Indiana will stray from their position of legislative deference and past jurisprudence, void stare decisis, and adopt the doctrine of comparative fault through case law.

It may be possible to challenge the constitutionally of the comparative fault's exceptions. The Indiana Constitution provides that a citizen is allowed full recovery for injuries they have received from another. ${ }^{256}$ The common law tradition of contributory negligence, however, is well entrenched in the history and tradition of Indiana and the law itself. Based on this fact, a constitutional challenge is unlikely to succeed. Even though a strong constitutional case could be made, a constitutional challenge is not likely to be the most efficient answer to changing the law.

The most successful method would be a change in the law itself by the citizens of Indiana. This could be done by placing an initiative on the ballot or placing pressure on the state legislature to introduce an amendment to the CFA. The CFA was strongly influenced by lobbyists, especially from the medical liability insurance lobby. ${ }^{257}$ Their stance against the adoption of comparative fault

254. These four states are: Alabama, Maryland, North Carolina, and Virginia.

255. American Medical Association, "Medical Liability Crisis Map," AMA NEws AND INFORMATION, (January 2007), available at http://www.wisconsinmedicalsociety.org/_WMS /communication/press_release/med_liab_jan07.pdf.

256. IND. CONST. ART. $1 \S 12$.

257. Bayliff, supra note 142 , at 863 . 
stalled two attempts to adopt the doctrine in committee in 1973 and $1981 .^{258}$ It is likely that this was the same lobby responsible for the CFA, which passed with the health care exception. State legislatures are elected officials and work for the people of the state. Therefore, the most effective way to make change to the law is to force the representatives to work for the people and adopt laws that the people choose. The CFA as it stands represents special interest groups and works against the state's citizens. It makes sense that the only people who have the capacity to change the law are the people who the law affects. Thus, the people of Indiana, calling for an amendment to abolish the doctrine of contributory negligence in medical malpractice cases, is the most likely, and possibly the only way, to change the law of the State.

\section{CONCLUSION}

The Indiana legislature adopted the Medical Malpractice Act in 1976 to deal with a health care crisis. In 1983, the Indiana General Assembly moved the state of Indiana in line with the majority of jurisdictions by passing the Comparative Fault Act. Indiana, however, is out of step with the majority in allowing medical malpractice cases to maintain the doctrine of contributory negligence as a defense. Besides Indiana, there are seven other states that are not facing nor are in jeopardy of facing a health care crisis. Of those, Indiana is the only state that still adheres to the doctrine of contributory negligence in medical malpractice cases.

There is no evidence to show that by adopting the doctrine of "modified" comparative fault that Indiana will be sent into another medical care crisis. Judging by the seven other states systems, comparative fault does not seem to be a factor at all. The most telling and only consistent element is the implementation of a punitive damages cap. Indiana has a hard cap on all punitive and economic damages, while the other states cap only economic or non-economic damages. This places Indiana in better shape on damages than the other states.

While there is strong evidence for removing the unfair and archaic doctrine of contributory negligence from Indiana law, achieving this goal will be much more difficult. The Indiana Supreme Court has continued to uphold the text of the Indiana Code. Absent the courts' willingness to overturn the legislature, the only route is for the legislature to amend the law. In order to accomplish this daunting task, a grass roots effort, supported by patient advocate groups, will need to pressure the legislature into giving patients a fair shot at recovery when they are harmed by the misdeeds of a physician. There will likely be strong opposition from interest groups, backed by a strong lobby, to keep the unfair system in place. It provides the insurance companies and physicians an avenue to avoid liability altogether. The citizens of Indiana must speak out and remind the legislators of their purpose and function. The members of the 
Indiana General Assembly represent the citizens of Indiana, not the lobbyist and special interest groups. 